\title{
Chemical-bromatological characteristics of forage sorghum varieties irrigated with saline effluents from fish farming
}

Welson Lima Simões"*, Miguel Julio Machado Guimarães², Gherman Garcia Leal de Araújo', Lilia Gomes Willadino ${ }^{3}$, Alexandre Fernandes Perazzo ${ }^{4}$, Letícia dos Santos Belfor ${ }^{5}$

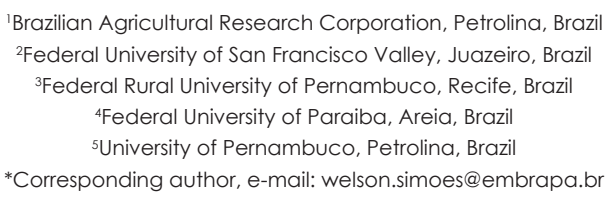

\begin{abstract}
The objective of this work was to evaluate the chemical and bromatological characteristics of forage sorghum varieties subjected to different leaching fractions of saline effluents from fish farming in the Semiarid region of Brazil. The experiment was conducted in a randomized block design, in a $3 \times 4$ factorial arrangement with four replications, consisting of three forage sorghum varieties (Volumax, F305, and Sudão) and four leaching fractions $(0 \%, 5 \%, 10 \%$, and $15 \%$ ) of saline (electrical conductivity of $2.5 \mathrm{dS} \mathrm{m}^{-1}$ ) effluent from fish farming. The organic matter, dry matter, mineral matter, crude protein, neutral detergent fiber (NDF), acid detergent fiber, lignin, hemicellulose, and cellulose contents of the plants were evaluated. The crude protein contents of the plant components, and mineral matter content of leaves and panicles increased, and the NDF of leaves decreased in treatments with the highest leaching fractions. The F305 variety presented better chemical-bromatological characteristics compared to the other sorghum varieties evaluated.
\end{abstract}

Keywords: Irrigation management. Salinity. Sorghum bicolor (L.) Moench.

\begin{abstract}
Introduction
Forage availability in Brazil is irregular throughout the year due to climatic conditions, with alternating periods of pasture surplus and shortage. This situation is even worse in the Brazilian Semiarid region, where water resources are scarce and do not meet the needs of human consumption and agricultural activities, and part of the groundwater and surface water sources present high salt contents (Vieira et al., 2005).

Saline waters taken from wells are commonly used for fish farming, whose management methods have generated saline effluents, which are little studied. Due to the water
\end{abstract}

scarcity in this region, these effluents can be used for irrigation of plants that are tolerant to salinity.

The use of these saline water requires the application of irrigation water depths that leach part of the salts through the soil. It is essential to reduce soil salinity in the root system area of the plant and ensure the crop productivity. Thus, an ideal water depth that meets the needs of the plant and removes the excess of harmful salts, without causing a nutritional deficiency that damages the crop, must be defined (Aragüésa et al., 2014).

Forage sorghum (Sorghum bicolor (L.) Moench) presents high energy value for animal 
feed and is highly adapted to dry and hot environments, which limits the growing of other forage species (Buso et al., 2011). It presents high biomass yields per unit area and has been adapted to the silage process (Neumann et al., 2002), thus, it is an alternative for fodder in these environments.

The genetic variability of this crop allowed the development of several breeding programs that generated high number of hybrids and varieties. These materials have different agronomic characteristics and nutritive values, with consequent variations in productivity and morphology, resulting in forages of different qualities. The chemical-bromatological characteristics of sorghum plants can be affected by several factors besides the genetic material, including the cultivation site (Albuquerque et al., 2013) fertilization (Santos et al., 2014b), and water availability (Tardin et al., 2013) and salinity (Guimarães et al., 2016).

In this context, the objective of this work was to evaluate the chemical and bromatological characteristics of forage sorghum varieties subjected to different leaching fractions of saline effluents from fish farming in the Semiarid region of Brazil.

\section{Material and methods}

The experiment was conducted in 2013 at the Caatinga Experimental Field of the Embrapa Semiarid, in Petrolina PE, Brazil (9०8'8.9"S, $40^{\circ} 18^{\prime} 33.6^{\prime \prime} \mathrm{W}$, and altitude $373 \mathrm{~m}$ ). The climate of this region is BSWh', semiarid, according to the Köppen classification. The average air relative humidity in the study period was $63.86 \%$ and the average temperature was $25.46{ }^{\circ} \mathrm{C}$, with maximum evapotranspiration of $6.97 \mathrm{~mm}$ day 1, and average evapotranspiration of $5.85 \mathrm{~mm}$ day $^{-1}$. The small precipitation events occurred in the study period were concentrated in the first 10 days after planting (DAP) and at 74 DAP, totaling $32.7 \mathrm{~mm}$ in the crop cycle.
The soil of the experimental area was classified as Red-Yellow Argissolo (EMBRAPA, 2006) (Ultisol) of medium texture and presented flat relief. It was prepared according to the needs of the crop, with plowing and harrowing, and fertilized with $30 \mathrm{~kg} \mathrm{ha}^{-1}$ of nitrogen, $60 \mathrm{~kg} \mathrm{ha}^{-1}$ of phosphorus and $20 \mathrm{~kg}$ ha- of potassium based on a previous soil analysis, which showed electrical conductivity of $1.81 \mathrm{dS} \mathrm{m}^{-1}$, pH of $5.6,1.4 \mathrm{cmol}_{\mathrm{c}}$ $\mathrm{dm}^{-3}$ of $\mathrm{Mg}, 2.35 \mathrm{cmol}_{\mathrm{c}} \mathrm{dm}^{-3}$ of $\mathrm{Ca}, 2.4 \mathrm{cmol}_{\mathrm{c}} \mathrm{dm}^{-3}$ of $\mathrm{H}+\mathrm{Al}, 0.6 \mathrm{cmol}_{\mathrm{c}} \mathrm{dm}^{-3}$ of $\mathrm{K}, 0.72 \mathrm{cmol}_{\mathrm{c}} \mathrm{dm}^{-3}$ of $\mathrm{Na}$, $75.9 \%$ of sand, and $14.9 \%$ of silt. Nitrogen fertilizer (30 $\mathrm{kg} \mathrm{ha}^{-1}$ ) was applied at 30 DAP, according to the recommendations for the crop for the state of Pernambuco, Brazil (Cavalcanti, 2008). Sowing was carried out in April 2013, and the seedling emergence occurred at 7 DAP.

The experiment was conducted in a randomized block design, in a $3 \times 4$ factorial arrangement with four replications, consisting of three forage sorghum varieties (Volumax, F305, and Sudão) and four leaching fractions $(0 \%, 5 \%$, $10 \%$, and $15 \%$ ) of saline (electrical conductivity of $2.5 \mathrm{dS} \mathrm{m}^{-1}$ ) effluent from fish farming. The experimental unit consisted of five 5-meter rows of plants with 10 plants per meter and spacing of $0.5 \mathrm{~m}$ apart, and the evaluation area consisted of the 3 central meters of the three central rows $\left(12.5 \mathrm{~m}^{2}\right)$.

The plants were irrigated daily using a surface drip irrigation system connected to fish tanks containing black tilapia at density of 40 fish per cubic meter. Fifty percent of the water of the fish tanks was pumped daily into storage tanks to be used for irrigation, and then the fish tanks were replenished. The electrical conductivity of the fish effluent was monitored weekly using a portable digital conductivity meter; it remained at approximately $2.57 \mathrm{dS} \mathrm{m}^{-1}$.

The chemical characteristics of the irrigation water from the fish farming were determined weekly, before and during the experiment (Table 1).

Table 1. Chemical characteristics of the irrigation water from the fish farming

\begin{tabular}{|c|c|c|c|c|c|c|c|c|}
\hline $\mathrm{Ca}^{2+}$ & $\mathrm{Mg}^{2+}$ & $\mathrm{Na}^{+}$ & $\mathrm{K}^{+}$ & $\mathrm{Cl}^{-}$ & $\mathrm{pH}$ & $\mathrm{EC} 25^{\circ} \mathrm{C}$ & Hardness $\mathrm{CaCO}_{3}$ & SAR \\
\hline \multicolumn{6}{|c|}{$\mathrm{mmol}_{\mathrm{c}} \mathrm{L}^{-1}$} & $\mathrm{dS} \mathrm{m}^{-1}$ & $\mathrm{mg} \mathrm{L}^{-1}$ & \\
\hline 12.6 & 7.7 & 7.2 & 0.34 & 35.2 & 8.19 & 2.57 & 50.75 & 2.26 \\
\hline
\end{tabular}


The irrigation water depths were calculated according to the crop evapotranspiration (ETO * $\mathrm{KC}$ ) in the period between irrigations, considering the water application efficiency of the irrigation system (0.9). The Kc used followed the recommendation of Allen et al. (2006). The cultural practices consisted of manual weeding at 30 DAP, and preventive insecticide application at 40 and 60 DAP.

The plants were harvested in July when the grains were at the farinaceous stage, 92 DAP. The plants of the evaluation area of the plots were cut at a height of $10 \mathrm{~cm}$ from the ground, separated into panicle, leaves, and stem, and weighed separately. Subsamples of each plant component were dried at $65^{\circ} \mathrm{C}$ until constant weight to estimate their dry matter content and calculate their proportions.

The organic matter, dry matter, mineral matter, crude protein, neutral detergent fiber (NDF), acid detergent fiber (ADF), and lignin contents in the pre-dried samples of the plant, and plant components were determined. Hemicellulose contents were calculated by the difference between NDF and ADF, and cellulose contents by the difference between ADF and lignin.
The data were subjected to analysis of variance (ANOVA) using the Sisvar 5.0 program. Significant means were subjected to first-degree and second-degree regression models at $1 \%$ and $5 \%$ probability level to compare the leaching fractions. The Tukey's test at $5 \%$ probability was used to compare the varieties.

\section{Results and discussion}

The interaction between varieties and leaching fractions had no effect on the studied variables. The leaching fractions had no effect ( $p>0.05$ ) on the leaf, stem, and panicle dry matter, ADF, cellulose, hemicellulose, and lignin contents.

The varieties had effect $(p<0.05)$ on the plant components (Table 2). The leaf dry matter had higher proportion $(24.6 \%)$ in relation to the total dry matter than the other plant components of the F305 variety. This result confirms those reported by Albuquerque et al. (2013), who evaluated seven genotypes of sorghum in Leme do Prado MG, Brazil, and found higher proportion of leaves for this variety. The Volumax variety had similar leaf proportion to those reported by Avelino et al. (2011), and Botelho et al. (2010), varying from $20.69 \%$ to $25.16 \%$ in relation to the total dry matter.

Table 2. Percentages of leaf, stem, and panicle dry matter in relation to the total dry matter of forage sorghum plants irrigated with saline effluent from fish farming.

\begin{tabular}{cccc}
\hline Variety & Leaf & Stem & Panicle \\
\hline Volumax & $21.8 \mathrm{~b}$ & $53.1 \mathrm{c}$ & $25.1 \mathrm{a}$ \\
F305 & $24.6 \mathrm{a}$ & $59.7 \mathrm{~b}$ & $15.7 \mathrm{~b}$ \\
Sudão & $20.0 \mathrm{~b}$ & $68.0 \mathrm{a}$ & $12.0 \mathrm{C}$ \\
\hline Mean & 22.2 & 60.3 & 17.6 \\
CV (\%) & 12.52 & 6.60 & 13.19 \\
\hline Means followed by the same letter in the columns do not differ by the Tukey's test at 5\% probability.
\end{tabular}

The Sudão variety presented a lower $(p<0.05)$ proportion of leaves, with stems representing $68 \%$ of the total dry matter, whereas the F305 had $59.7 \%$, and Volumax had $53.1 \%$. In the context of conservation of forages for feeding ruminants, the percentage of stems of the plants is important for the lactic fermentation of the silage because of their higher concentrations of soluble carbohydrates, which are the main substrate for an adequate fermentation with lower losses of ensiled matter (Zanine et al. al., 2007).

The Volumax variety presented greater proportion of the panicle $(p<0.05)$ in the total dry matter, denoting the great potential of this variety to increase the sorghum silage quality. This component presents higher nutritive value than the other components of the plant, and high dry matter contents in this variety (Albuquerque et al., 2013; Cabral et al, 2003).

The production variables are affected by the percentages of the leaf, stem, and panicle components. According to Perazzo et al. (2014), although forage sorghums present high yields of dry matter, their nutritional values may be 
low due to their higher percentage of stems in relation to leaves, and panicles. Perazzo et al. (2014) evaluated 32 forage sorghum cultivars in the Brazilian Semiarid region and found a positive correlation between stem percentage and total dry matter.

The leaf dry matter content of the different sorghum varieties presented no difference ( $p>0.05$ ) (Table 3), with mean of $33 \%$. The leaf dry matter content affected $(p<0.05)$ the stem, panicle, and total dry matter of the plants. The use of forage sorghum cultivars that have succulent or dry stems may explain the differences in dry matter content of the varieties studied. The stem dry matter content of the F305 variety (32.68\%) indicated its dry stem characteristic, whereas Volumax (25.58\%), and Sudão (25.46\%) had succulent stems, denoting their higher concentration of soluble carbohydrates, and suitability for ensiling. The percentage of panicle $(p<0.05)$ was affected by the varieties, with higher values for Volumax (39.39\%) and Sudão (34.81\%).

The Volumax, and F305 varieties had higher total dry matter contents, which were affected by the panicle and stem dry matter, respectively. França et al. (2011) evaluated the quality of silages of hybrid sorghums and found total dry matter varying from $21.6 \%$ to $28.7 \%$. In the present study, the total dry matter varied from $27.82 \%$ to $32.84 \%$. These values were adequate, since total dry matter content must be above $25 \%$, and with an adequate level of soluble carbohydrates for an adequate fermentation in the ensiling process. (Mc Donald; Henderson; Heron, 1991)

The F305 variety had higher leaf (93.56\%), stem (94.79\%), and total (94.53\%) organic matter contents, followed by the Volumax, with $94.26 \%$ (stem), and $93.92 \%$ (total). The organic matter contents of the panicle component presented no difference $(p>0.05)$ between the varieties. The Sudão variety presented higher $(p<0.05)$ leaf, stem, and total mineral matter contents than the other varieties, denoting its higher genetic potential to uptake soil salts. This is a characteristic that is important for the Semiarid region of the Northeast of Brazil because several production systems in this region use saline water, and soils under salinization processes.

Table 3. Organic matter, dry matter, mineral matter, and crude protein of forage sorghum varieties grown under different leaching fractions of saline effluent from fish farming.

\begin{tabular}{|c|c|c|c|c|}
\hline \multirow{2}{*}{ Variety } & Leaf & Stem & Panicle & Total \\
\hline & \multicolumn{4}{|c|}{ Dry matter (\%) } \\
\hline Volumax & $33.59 \mathrm{a}$ & $25.58 \mathrm{~b}$ & $39.39 \mathrm{a}$ & $31.02 \mathrm{ab}$ \\
\hline F305 & $35.22 \mathrm{a}$ & $32.68 \mathrm{a}$ & $29.23 b$ & $32.84 \mathrm{a}$ \\
\hline Sudão & $30.53 a$ & $25.46 \mathrm{~b}$ & $34.81 \mathrm{ab}$ & $27.82 \mathrm{~b}$ \\
\hline Mean & 33.11 & 27.91 & 34.48 & 30.56 \\
\hline \multirow[t]{2}{*}{$C \vee(\%)$} & 16.99 & 14.32 & 20.87 & 12.88 \\
\hline & \multicolumn{4}{|c|}{ Organic matter (\%) } \\
\hline Volumax & $91.89 \mathrm{~b}$ & $94.26 \mathrm{a}$ & $94.95 a$ & $93.92 \mathrm{a}$ \\
\hline F305 & $93.56 a$ & $94.79 \mathrm{a}$ & $95.04 \mathrm{a}$ & $94.53 a$ \\
\hline Sudão & $90.55 \mathrm{C}$ & $93.28 \mathrm{~b}$ & $94.52 \mathrm{a}$ & $92.9 \mathrm{~b}$ \\
\hline Mean & 92.00 & 94.11 & 94.84 & 93.78 \\
\hline \multirow[t]{2}{*}{$C \vee(\%)$} & 1.09 & 1.03 & 0.87 & 0.82 \\
\hline & \multicolumn{4}{|c|}{ Mineral matter (\%) } \\
\hline Volumax & $8.11 \mathrm{~b}$ & $5.74 \mathrm{~b}$ & $5.05 a$ & $6.08 \mathrm{~b}$ \\
\hline F305 & $6.44 \mathrm{c}$ & $5.21 \mathrm{~b}$ & $4.96 a$ & $5.47 \mathrm{~b}$ \\
\hline Sudão & $9.45 a$ & $6.72 \mathrm{a}$ & $5.48 \mathrm{a}$ & $7.10 a$ \\
\hline Mean & 8.00 & 5.89 & 5.16 & 6.22 \\
\hline \multirow[t]{2}{*}{$\mathrm{CV}(\%)$} & 12.51 & 16.52 & 16.05 & 12.4 \\
\hline & \multicolumn{4}{|c|}{ Crude protein (\%) } \\
\hline Volumax & $12.5 a$ & $3.6 \mathrm{a}$ & $11.0 \mathrm{a}$ & $7.40 a$ \\
\hline F305 & $9.4 \mathrm{~b}$ & $2.6 \mathrm{~b}$ & $10.4 \mathrm{~b}$ & $5.5 \mathrm{c}$ \\
\hline Sudão & $12.8 \mathrm{a}$ & $3.9 \mathrm{a}$ & $11.2 \mathrm{a}$ & $6.55 \mathrm{~b}$ \\
\hline Mean & 11.5 & 3.4 & 10.9 & 6.48 \\
\hline$C \vee(\%)$ & 9.32 & 8.86 & 5.26 & 7.9 \\
\hline
\end{tabular}


The crude protein contents of the sorghum varieties differed $(p<0.05)$. The F305 variety had the lowest crude protein contents in all plant components, and total plant. Volumax and Sudão had equal crude protein contents in the leaves (Volumax 12.5\%, and Sudão 12.8\%), stems (Volumax 3.6\%, and Sudão 3.8\%) and panicles (Volumax 11.0\%, and Sudão 11.2\%). The Volumax variety had higher $(p<0.05)$ total crude protein content $(7.40 \%)$ than the other varieties due to the greater proportion of the panicle component of this variety (Table 2), denoting the potential of the panicle component to increase the nutritive value of sorghum. These results confirm those found by other authors (Silva et al., 2011 ; Neumann et al., 2002; Cabral et al., 2003).

The stem of all varieties presented lower crude protein contents than the other plant components, with an average of $3.4 \%$. This confirm the results reported by Albuquerque et al. (2013), who found stem crude protein contents of $2.88 \%$ to $3.66 \%$ when evaluating seven forage sorghum varieties in different locations. Therefore, this is the main component responsible for decreasing silage quality, in terms of nutritional value.

Neutral detergent fiber (NDF), acid detergent fiber (ADF), hemicellulose, cellulose, and lignin contents of the plant components of the sorghum varieties evaluated are shown in Table 4. The Sudão variety had lower $(p<0.05)$ leaf NDF (60.73\%), and hemicellulose (27.77\%) contents; and F305 had lower $(p<0.05)$ leaf lignin (7.95\%) content. The leaf ADF contents of the varieties evaluated were equal $(p<0.05)$.

Table 4. Neutral detergent fiber (NDF), acid detergent fiber (ADF), hemicellulose, cellulose, and lignin contents of forage sorghum varieties grown under different leaching fractions of saline effluent from fish farming.

\begin{tabular}{|c|c|c|c|c|}
\hline \multirow{2}{*}{ Variety } & Leaf & Stem & Panicle & Total \\
\hline & \multicolumn{4}{|c|}{ NDF } \\
\hline Volumax & $64.44 \mathrm{a}$ & $64.90 \mathrm{a}$ & $54.65 \mathrm{~b}$ & $62.09 a$ \\
\hline F305 & $64.26 \mathrm{a}$ & $54.48 \mathrm{c}$ & $50.93 \mathrm{~b}$ & $56.30 \mathrm{~b}$ \\
\hline Sudão & $60.73 \mathrm{~b}$ & $58.51 \mathrm{~b}$ & $66.19 a$ & $59.95 a$ \\
\hline Mean & 63.14 & 59.30 & 57.26 & 59.45 \\
\hline \multirow[t]{2}{*}{ CV (\%) } & 4.32 & 7.44 & 12.56 & 4.25 \\
\hline & \multicolumn{4}{|c|}{ ADF } \\
\hline Volumax & $32.74 \mathrm{~ns}$ & $40.88 \mathrm{a}$ & $24.89 \mathrm{~b}$ & $34.99 a$ \\
\hline F305 & 30.93 ns & $29.90 \mathrm{C}$ & $22.72 b$ & $28.97 \mathrm{~b}$ \\
\hline Sudão & $32.96^{\mathrm{ns}}$ & $34.17 \mathrm{~b}$ & $35.82 a$ & $34.16 a$ \\
\hline Mean & 32.21 & 34.98 & 27.82 & 32.71 \\
\hline \multirow[t]{2}{*}{ CV (\%) } & 8.33 & 6.11 & 12.64 & 4.1 \\
\hline & \multicolumn{4}{|c|}{ Hemicellulose } \\
\hline Volumax & $31.69 \mathrm{a}$ & 24.02 ns & $29.75^{\mathrm{ns}}$ & $27.10 a$ \\
\hline F305 & $33.33 a$ & 24.58 ns & $28.2^{\mathrm{ns}}$ & $27.33 a$ \\
\hline Sudão & $27.77 b$ & 24.34 ns & 30.36 ns & $25.79 a$ \\
\hline Mean & 30.93 & 24.31 & 29.44 & 26.75 \\
\hline \multirow[t]{2}{*}{ CV (\%) } & 12.36 & 17.7 & 21.82 & 9.44 \\
\hline & \multicolumn{4}{|c|}{ Cellulose } \\
\hline Volumax & $22.63^{n s}$ & $31.94 \mathrm{a}$ & $15.89 \mathrm{~b}$ & $25.80 a$ \\
\hline F305 & $22.98 \mathrm{~ns}$ & $22.54 \mathrm{C}$ & $16.29 \mathrm{~b}$ & $21.6 \mathrm{~b}$ \\
\hline Sudão & $22.06^{\mathrm{ns}}$ & $26.41 \mathrm{~b}$ & $22.69 a$ & $25.14 a$ \\
\hline Mean & 22.55 & 26.96 & 18.29 & 24.18 \\
\hline \multirow[t]{2}{*}{$C \vee(\%)$} & 11.91 & 12.25 & 18.93 & 9.59 \\
\hline & \multicolumn{4}{|c|}{ Lignin } \\
\hline Volumax & $10.11 a$ & $8.94^{\mathrm{ns}}$ & $9.01 \mathrm{~b}$ & $9.18 a$ \\
\hline F305 & $7.95 b$ & $7.36^{\mathrm{ns}}$ & $6.43 c$ & $7.38 \mathrm{~b}$ \\
\hline Sudão & $10.61 \mathrm{a}$ & $7.67 \mathrm{~ns}$ & $12.56 a$ & $9.02 \mathrm{ab}$ \\
\hline Mean & 9.56 & 7.99 & 9.33 & 8.53 \\
\hline CV (\%) & 23.06 & 31.25 & 28.01 & 23.6 \\
\hline
\end{tabular}

The F305 variety presented lower denoting a better stem quality. The Volumax $(p<0.05)$ stem NDF $(54.48 \%), \operatorname{ADF}(29.90 \%)$, and variety presented higher $(p<0.05)$ values for all cellulose $(22.54 \%)$ than the other varieties, parameters evaluated in the stem component, 
and no differences ( $p>0.05$ ) for hemicellulose, and lignin, when compared to the other varieties.

The Volumax and F305 varieties presented lower $(p<0.05)$ panicle NDF, ADF, and cellulose contents. The F305 presented lower $(p<0.05)$ panicle lignin content than the other varieties (6.43\%).

The F305 variety had lower $(p<0.05)$ total NDF, ADF, cellulose, and lignin contents than the other varieties, denoting a better nutritional quality of the cell wall components.

Stem quality is determinant to a satisfactory forage sorghum; it has greater participation on the nutritive value of the plant because it presents greater proportion than the other components. According to Flaresso, Gross, and Almeida (2000), the stem component can affect negatively the nutritional quality of silages due to its greater fiber contents. However, increases of panicle contents in the silage composition increase non-fibrous carbohydrate contents, thus improving its nutritional value (Cabral et al., 2003).

The leaching fractions had significant effect $(p<0.05)$ on crude protein, organic matter, mineral matter, and NDF contents. The crude protein content of the forage sorghum varieties
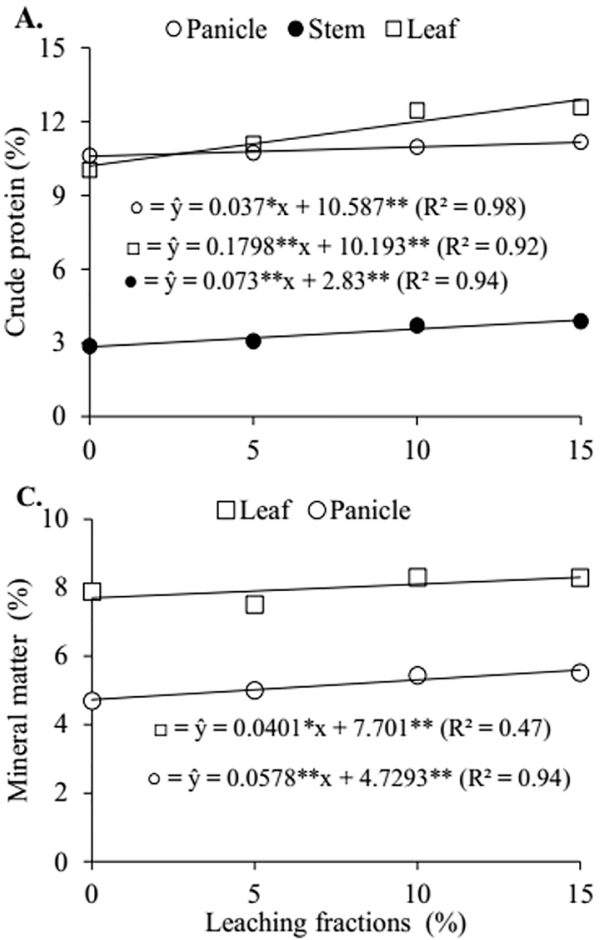

Figure 1. Crude protein (A), organic matter (B), mineral matter (C), and neutral detergent fiber (NDF) (D) of forage sorghum varieties grown under different leaching fractions of saline effluent from fish farming. ${ }^{*}=$ significant at $5 \%$ probability; ${ }^{* *}=$ significant at $1 \%$ probability.

increased with increasing leaching fractions (Figure 1). Increasing leaching fractions results in lower electrical conductivities through the soil profile around the root system of the crop (Assis Junior et al., 2007, Guimarães et al., 2016, Simões et al., 2016); this may have affected the evaluated characteristics. The lowest leaching fractions decreased crude protein contents in all evaluated components of the plant (stem, leaves, and panicle). These decreases in protein contents may be due to reductions in nitrogen uptake by the plant, or changes in assimilate distribution in the plant (Vieira et al., 2005). the organic matter content and, consequently, increased the mineral matter content in the leaves and panicles of the sorghum varieties evaluated. These increases in mineral matter represent the plants' ability to extract greater amounts of salts from the soil; this is a positive characteristic when the plants are under saline water or soils, since salt accumulations in the soil is an indicator of environmental degradation in semiarid regions and threatens the sustainability of irrigated agriculture in these regions (Azevedo et al., 2005).
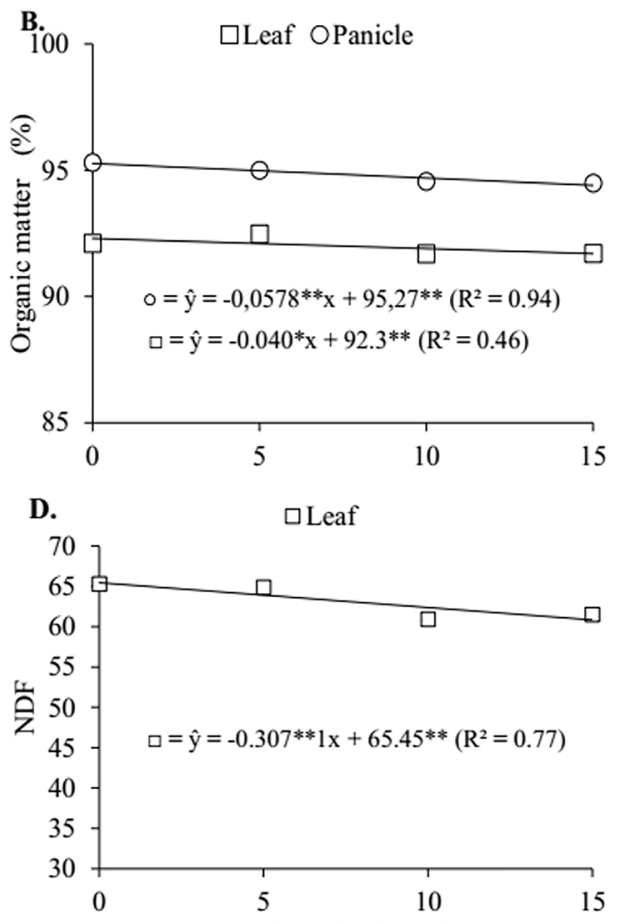

Leaching fractions $(\%)$

The leaching fractions used reduced 
The results showed a decrease in the leaf NDF of the plants with increasing leaching fraction of the saline water from fish farming (Figure 1D). Different results were found by Santos et al. (2013), Santos et al. (2014a), and Vieira et. al (2005). These authors found no effect of salinity on NDF in forage sorghum genotypes.

\section{Conclusions}

1. The application of leaching fractions of up to $15 \%$ increased the crude protein, and mineral content in the components of the forage sorghum plants evaluated.

2. The F305 variety presented better chemical-bromatological quality than the other varieties of sorghum when grown under irrigation with saline effluent from fish farming.

\section{References}

ALBUQUERQUE, C. J. B.; JARDIM, R. R.; ALVES, D. D.; GUIMARÃES, A. S.; PORTO, E. M. V. 2013. Características agronômicas e bromatológicas dos componentes vegetativos de genótipos de sorgo forrageiro em Minas Gerais. Revista Brasileira de Milho e Sorgo, 12: 164-182.

ALLEN, R; PEREIRAS, L. S.; RAEKS, D.; SMITH, M. 2006. Evapotranspiración del cultivo, Guías para la determinación de los requerimientos de agua de los cultivos, Estudio FAO Riego y Drenaje, No. 56, Roma, Italia, 298p.

ASSIS JUNIOR, J. O.; LACERDA, C. F.; SILVA, C. F.; SILVA, F. L. B.; BEZERRA, M. A.; GHEYI, H. R. 2007. Produtividade do feijão-de-corda e acúmulo de sais no solo em Função da fração de lixiviação e da salinidade da água de Irrigação. Engenharia Agrícola, 27: 702-713.

ARAGÜÉSA, R.; MEDINAA, E. T.; CLAVERÍAA, I.; MARTÍNEZ-COBB, A.; FACIA, J. 2014. Regulated deficit irrigation, soil salinization and soil sodification in a table grape vineyard dripirrigated with moderately saline Waters. Agricultural Water Management. 134: 84-93.

AQUINO, A. J. S.; LACERDA, C. F.; GOMES-FILHO, E. 2007. Crescimento, partição de matéria seca e retenção de $\mathrm{Na}+, \mathrm{K}+$ e $\mathrm{Cl}$ - em dois genótipos de sorgo irrigados com águas salinas. Revista Brasileira de Ciência do Solo. 31: 961-971.

AVELINO, P. M.; NEIVA, J. N. M.; ARAUJO, V. L.; ALEXANDRINO, E.; SANTOS, A. C.; RESTLE, J. 2011. Características agronômicas e estruturais de híbridos de sorgo em função de diferentes densidades de plantio. Revista Ciência Agronômica. 42: 534-541.
AZEVEDO, C. M. B.; PEDROSA, G. P.; MEDEIROS, J. F.; NUNES, G. H. S. 2005. Uso de Atriplex nummularia na extração de sais de solos irrigados com efluentes salinos. Revista Brasileira de Engenharia Agrícola e Ambiental 9: 300-304.

BOTELHO, P. R. F.; PIRES, D. A. A.; SALES, E. C. J.; ROCHA JUNIOR, V. R.; REIS, S. T. 2010. Avaliação de genótipos de sorgo em primeiro corte e rebrota para produção de silagem. Revista Brasileira de Milho e Sorgo 9: 287-297.

BUSO, W. H. D.; MORGADO, H. S.; BORGES E SILVA, L.; FRANÇA, A. F. S. 2011. Utilização do sorgo forrageiro na alimentação animal. PUBVET 5.

CABRAL, L. SILVA; VALADARES FILHO, S. C.; DETMANN, E.; ZERVOUDAKIS, J. T.; PEREIRA, O. G.; VELOSO, R. G. 2003. Composição químicobromatológica, produção de gás, digestibilidade in vitro da matéria seca e NDT estimado da silagem de sorgo com diferentes proporções de panículas. Revista Brasileira de Zootecnia 32: 1250-1258.

CAVALCANTI, F. J. DE A. 2008. Recomendações de adubação para o Estado de Pernambuco. $2^{a}$ Apr. 3.ed., Recife: IPA, 212p.

EMPRESA BRASILEIRA DE PESQUISA AGROPECUÁRIA - EMBRAPA. 2006. Centro Nacional de Pesquisa de Solos. Sistema brasileiro de classificação de solos. 2.ed. Rio de Janeiro: EMBRAPA, $306 \mathrm{p}$.

FEIJÃO, A. R.; SILVA, J. C. B.; MARQUES, E. C.; PRISCO,J. T.; GOMES FILHO, E. 2011. Efeito da nutrição de nitrato na tolerância de plantas de sorgo sudão à salinidade. Revista Ciência Agronômica 42: 675-683.

FLARESSO, J. A.; GROSS, C. D.; ALMEIDA, E. X. 2000. Cultivares de milho e sorgo para ensilagem no Alto Vale do Itajaí, Santa Catarina. Revista Brasileira de Zootecnia 29: 1608-1615.

FRANÇA, A. F. S.; OLIVEIRA, R. P.; MIYAGI, E. S.; SILVA, A. G.; PERÓN, H. J. M. C.; BASTO, D. C. 2011. Características fermentativas da silagem de híbridos de sorgo sob doses de nitrogênio. Ciência Animal Brasileira 12: 383-391.

GUIMARÃES, M. J. M.; SIMÕES, W. L.; TABOSA, J. N.; SANTOS, J. E.; WILLADINO, L. 2016. Cultivation of forage sorghum varieties irrigated with saline effluent from fish-farming under semiarid conditions. Revista Brasileira de Engenharia Agrícola e Ambiental. 20: 461-465.

MORAES, S. D.; JOBIM, C. C.; SILVA, M. S.; MARQUARDT, F. I. 2013. Produção e composição química de híbridos de sorgo e de milho para silagem. Revista Brasileira de Saúde e Produção Animal 14: 624-634. 
NEUMANN, M; RESTLE, J.; ALVES FILHO, D. C.; BERNARDES, R. A. C.; ARBOITE, M. Z.; CERDÓTES, L.; PEIXOTO, L. A. O. 2002. Avaliação de diferentes híbridos de sorgo (Sorghum bicolor, L. Moench) quanto aos componentes da planta e silagens produzidas. Revista Brasileira de Zootecnia 31: 302-312.

PERAZZO, A. F.; CARVALHO, G. G. P.; SANTOS, E. M.; PINHO, R. M. A.; CAMPOS, F. S.; MACEDO, C. H. O.; AZEVÊDO, J. A. G.; TABOSA, J. N. 2014. Agronomic evaluation of 32 sorghum cultivars in the Brazilian semi-arid region. Revista Brasileira de Zootecnia 45: 232-237.

SANTOS, D. B.; VOLTOLINI, T. V.; AZEVEDO, C. A. V.; NOGUEIRA, D. M.; SILVA, A. S.; MEDEIROS, S. S. 2013. Tolerância do capim Marandu a salinidade. Revista Educação Agrícola Superior 28: 63-66.

SANTOS, D. B.; VOLTOLINI, T. V.; SANTOS, R. M.; AZEVEDO, D. O.; OLIVEIRA, R. G.; CHAGAS, E. C. O.; SANTOS, F. M.; NOGUEIRA, D. M. 2014a. Características produtivas e qualitativas do estilozantes campo grande submetido ao estresse salino. Global Science and Technology 7: 1-7.

SANTOS, F. C.; ALBUQUERQUE FILHO, M. R.; RESENDE, A. V.; OLIVEIRA, A. C.; GOMES, T. C.; OLIVEIRA, M. S. 2014b. Adubações nitrogenada e potássica no sorgo biomassa-produtividade e qualidade de fibra. Revista Brasileira de Milho e Sorgo 13: 1-13.

SANTOS, R. D.; PEREIRA, L. G. R.; NEVES, A. L. A.; RODRIGUES, J. A. S.; COSTA, C. T. F.; OLIVEIRA, G. F. 2013. Agronomic characteristics of forage sorghum cultivars for silage production in the lower middle San Francisco Valley. Acta Scientiarum. Animal Sciences 35: 13-19.

SILVA, T. C.; SANTOS, E. M.; AZEVEDO, J. A. G.; EDVAN, R. L.; PERAZZO, A. F.; PINHO, R. M. A.; RODRIGUES, J. A. S.; SILVA, D. S. 2011 . Agronomic divergence of sorghum hybrids for silage yield in the semiarid region of Paraiba. Revista Brasileira de Zootecnia. 40: 1886-1893.

SIMÕES, W. L.; YURI, J. E.; GUIMARÃES, M. J. M..; SANTOS, J. E.; ARAÚJO, E. F. J. 2016. Beet cultivation with saline effluent from fish farming. Revista Brasileira de Engenharia Agrícola e Ambiental. 20: 62-66.

TARDIN, F. D.; ALMEIDA FILHO, J. E.; OLIVEIRA, C. M.; LEITE, C. E. P.; MENEZES, C. B.; MAGALHÃES, P. C.; RODRIGUES, J. A. S.; SCHAFFERT, R. E. 2013. Avaliação agronômica de híbridos de sorgo granífero cultivados sob irrigação e estresse hídrico. Revista Brasileira de Milho e Sorgo 12: 102-117.
VIEIRA, M. R.; LACERDA, C. F.; CÂNDIDO, M. J. D.; CARVALHO, P. L.; COSTA, R.N.T.; TABOSA, J. N. 2005. Produtividade e qualidade da forragem de sorgo irrigado com águas salinas. Revista Brasileira de Engenharia Agrícola e Ambiental 9: 42-46.

ZANINE, A.M.; SANTOS, E.M.; FERREIRA, D.J.; PEREIRA, O. G. 2007. Populações microbianas e componentes nutricionais nos órgãos do capimtanzânia antes e após a ensilagem. Semina: Ciências Agrárias 28: 143-150. 